\title{
A “Great” Large Family: Understandings of Multiculturalism among Newcomers to Canada
}

\author{
Christopher J. Fries and Paul Gingrich
}

\begin{abstract}
Analysts have taken positions either supporting or attacking multicultural policy, yet there is insufficient research concerning the public policy of multiculturalism as it is understood and practiced in the lives of Canadians. This analysis approaches multiculturalism as a text which is constituent of social relations within Canadian society. Data from the Regina Refugee Research Project are analyzed within Nancy Fraser's social justice framework to explore the manner in which multiculturalism and associated policies are understood and enacted in the lived experience of newcomers. Newcomers' accounts of multiculturalism are compared with five themes identified via textual analysis of the Canadian Multiculturalism Act-diversity, harmony, equality, overcoming barriers, and resource. Embedded within the accounts newcomers offered of Canadian multiculturalism are relations of ruling that can be understood within the context of struggles for recognition and social justice. Further research is needed to investigate the relational processes in which differing perceptions of and experiences with multiculturalism are embedded and to compare the present accounts with those of other groups of immigrants and Canadian-born.
\end{abstract}

\section{Résumé}

Les analystes ont pris position soit pour ou contre la politique du multiculturalisme, mais il y a insuffisance de la recherche sur la politique publique du multiculturalisme tel qu'on le comprend et pratique dans la vie des Canadiens. Cette analyse aborde le multiculturalisme en tant que texte constitutif des relations sociales au sein de la société canadienne. Des données statistiques du Regina Refugee Research Project sont analysées dans le cadre de justice sociale élaboré par Nancy Fraser afin d'explorer la manière dont le multiculturalisme et les politiques connexes sont comprises et adoptées dans le vécu des nouveaux arrivants. Les témoignages de nouveaux arrivants sur le multiculturalisme sont comparés à cinq thèmes identifiés par l'analyse textuelle de la Loi sur le multiculturalisme canadien - la diversité, l'harmonie, l'égalité, la suppression des obstacles, et l'ingéniosité. Les nouveaux arrivants intègrent à leurs témoignages concernant le multiculturalisme canadien des relations de pouvoir qui peuvent être comprises dans le contexte de luttes pour la reconnaissance et la justice sociale. D'autres recherches sont nécessaires pour étudier les processus relationnels auxquels sont intégrées différentes perceptions et expériences du multiculturalisme et comparer les témoignages actuels avec ceux d'autres groupes d'immigrants et natifs du Canada. 
[To me, multiculturalism means] opportunities for all groups, cultures, or persons to develop or act within their community. The governments try to treat everybody as part of a 'great' large family.

Regina Refugee Study participant

[Canada is not] a melting pot in which the individuality of each element is destroyed in order to produce a new and totally different element. It is rather a garden into which have been transplanted the hardiest and bright est flowers from many lands, each retaining in its new environment the best of the qualities for which it was loved and prized in its native land.

The Right Honourable John Diefenbaker, former Canadian Prime Ministerl

\section{Introduction}

Perhaps no Canadian policy initiative has greater potential relevance for the lives of newcomers to Canada than does multiculturalism. Multiculturalism has been both widely applauded and subjected to much criticism. One reason for this ambivalence may be the variety of meanings associated with multiculturalism-it can refer to any of policy, program, practice, educational approach, sociological concept, symbol, ideal, ideology, theory, or description of Canadian society. No definitive meaning has been attached to the term and "as a federal policy multiculturalism is difficult to explicate since its substance remains obscure and the program content of multiculturalism is periodically modified." ${ }^{2}$ While many analysts have taken positions either supporting or attacking multicultural policy, ${ }^{3}$ there are few empirical studies of multicultural policy and its effects. ${ }^{4}$ In addition, there has been little in the way of empirical investigation ${ }^{5}$ into the ways Canadians perceive the policy and how the accounts of newcomers are implicated in the construction of multiculturalism as a feature of the Canadian ethnocultural landscape. Drawing upon Ng's conceptualization of Canadian multiculturalism as an "ideological frame," it becomes clear that implementation of the policy is a relational process that is "produced and constructed through human activities." 6 Consequently, the starting point for this analysis is approaching Canadian multiculturalism as a text which is constituent of social relations within the wider Canadian society: "In taking up a text as a constituent of a social relation, we are constrained not only to understand it as a moment in a sequence, but also to recognize that the interpretive practices which activate it are embedded in a relational process." 7 In this article we explore how multiculturalism and its associated policies and legislation are understood and enacted in the lived experience of newcomers to Canada. Data for this exploration come from interviews with newcomers to Regina, Saskatchewan, who arrived in the city as government-sponsored refugees. Before presenting our findings, we provide a historical and theoretical background for understanding multiculturalism.

\section{Historical and Theoretical Background}

Multicultural Policy in Canada

Multicultural policy is closely linked to the social, economic, and political history of Canadian society, and more specifically to immigration ${ }^{8}$ and the labour market, along with issues of citizenship and social justice. In English-speaking Canada prior to the 1960s, "integration" meant assimilation into a British model of society, although there were exceptions and assimilation was often incomplete. More recently, there have been changes in the composition of the population, in the structure of Canadian society, and in official policy and practice, so that integration in a multicultural context has become widely accepted. ${ }^{9}$ While this has created a greater degree of social justice in areas of cultural differences, inequalities of incomes and opportunities remain structured into the operation of the Canadian economy and society. ${ }^{10}$ These have not been eliminated, leading to dramatic differences in life experiences for individuals from different ethnocultural backgrounds.

Some writers have found historical precedents or continuities for federal multicultural policy, ${ }^{11}$ but most date the beginning to the early 1970s. ${ }^{12}$ Following the Royal Commission on Bilingualism and Biculturalism, appointed in 1963, the federal government "proclaimed a policy of multiculturalism within a bilingual framework."13 On October 8, 1971, Canadian Prime Minister Pierre Trudeau announced that federal government policy would officially be directed toward "preserving human rights, developing Canadian identity, strengthening citizenship participation, reinforcing Canadian unity and encouraging cultural diversification within a bilingual framework."14 In 1977, legal safeguards against discrimination based on race, ethnic origin, or religion were made law as part of the Canadian Human Rights Act. When the Canadian Constitution was patriated in 1982 the Charter of Rights and Freedoms enshrined guarantees of equality and multiculturalism in sections 15 and 27. And perhaps most significantly, on July 21, 1988, Bill C-93, an Act for the preservation and enhancement of multiculturalism in Canada, or the Canadian Multiculturalism Act (CMA) became law.

Responsibility for administering the policy was initially vested in the Multiculturalism Directorate of the Department of the Secretary of State and, after 1993, in the Department of Canadian Heritage. ${ }^{15}$ Following a 1996 review $^{16}$ Canadian Heritage established a renewed multiculturalism program with "social justice, identity 
and civic participation" as goals. ${ }^{17}$ Since 2008, multiculturalism policy and programs have been located in the Department of Citizenship and Immigration. ${ }^{18}$ Among the current emphases are inclusive citizenship, "reaching out to Canadians and newcomers and ... developing lasting relationships with ethnic and religious communities in Canada," identity, integration, equality, acceptance, and harmony. ${ }^{19}$

Multicultural policy in Canada has had both vociferous defenders and critics. Ministerial statements defending and promoting the federal policy and program ${ }^{20}$ have been accompanied by reports and polls that generally show public support. ${ }^{21}$ Academic analysis has provided historical, sociological, and theoretical support for multiculturalism. ${ }^{22}$ At the same time, opposition to and questioning of multiculturalism has come from some academics, ${ }^{23}$ writers and media analysts, ${ }^{24}$ and non-governmental organizations and political parties and groups. ${ }^{25}$ Changes in federal program structures and a shift in emphasis have been seen by some to weaken the federal commitment to multiculturalism. ${ }^{26}$ Despite this, multicultural policy continues to attempt to deal programmatically with cultural difference in an accepting manner, within the context of unequal relationships among individuals and groups. The policy is a means of countering homogenizing cultural tendencies in contemporary societies such as Canada. ${ }^{27}$ As such, multiculturalism is not an ethereal or merely platitudinous concept, but in dealing with disparate and unequal power relationships, the policy has direct consequence for how both Canadians and newcomers live and realize social aspirations. As an ideological process that is contested and subject to ongoing negotiation, multiple viewpoints on multicultural policy are inevitable. Ng employs textual analysis to demonstrate that Canadian multiculturalism "is through and through an artifact produced by the administrative processes of a liberal democratic state in a particular historical conjuncture to re-conceptualize and reorganize changing social, political, and economic realities." 28 As such, multicultural policies are inextricably bound up with issues of social justice.

\section{Multiculturalism and Social Justice}

The theoretical framework informing this analysis is provided by critical theorist Nancy Fraser's analysis of recognition within a social justice framework, examining sources of injustice in culturally diverse societies. ${ }^{29}$ In Fraser's framework, "social identities are discursively constructed in historically specific social contexts." ${ }^{30}$ As such, multicultural policy can be understood as constitutive of status orders such as "refugee." In Fraser's words, "status represents an order of intersubjective subordination derived from institutionalized patterns of cultural value that constitute some members of society as less than full partners in interaction." 31 This is social status not in terms of prestige or an index of socio-economic status, but in the Weberian sense of social honour and status group. ${ }^{32}$ This form of status affects how members of a society interact (or how some are not permitted to interact) with each other and the extent to which all members are considered full participants in social relationships.

Initially, Fraser's social justice framework ${ }^{33}$ identified two distinct social spheres that have associated with them different sources of injustice and different solutions to economic and cultural injustice. ${ }^{34}$ Her original model presents two overlapping but analytically distinct sources of inequality (maldistribution / misrecognition) with two solutions (redistribution / recognition). Later, Fraser ${ }^{35}$ would introduce a third dimension focusing on the issue of political representation within the context of global neo-liberalism. Here her concern is with the ways in which the political framing of social justice includes and excludes parties. In view of Fraser's later work, redistribution, recognition, and representation are understood as conjoined in struggles for social justice. The present analysis is grounded in the redistribution / recognition debate that is central to Fraser's earlier work.

Fraser argues that social injustice can be a result of maldistribution in the material sphere of society or misrecognition in the cultural and symbolic sphere. Maldistribution of resources is associated with exploitation, economic marginalization, and deprivation while misrecognition is associated with cultural domination, nonrecognition, and disrespect. ${ }^{36}$ However, Fraser argues that redistribution of economic resources will not necessarily solve problems of misrecognition; the latter are in the cultural or symbolic sphere and "the remedy for cultural injustice ... is some sort of cultural or symbolic change." 37 As such, Fraser sets misrecognition in the sphere of culture and the symbolic, emerging as a result of status subordination.

Fraser elaborates that each specific social inequality, such as discriminatory or inequitable treatment of immigrant groups, has elements of both maldistribution and misrecognition. Because of the close connection between maldistribution and misrecognition, social justice can be achieved only by tackling and eliminating the causes of both injustices. As such, she considers the material and symbolic spheres to be two distinct, but interlocking, dimensions of social life. Achieving social justice involves both redistribution of resources in the material sphere and achieving a form of recognition that allows all members of society to have the status of full partners in social interaction. ${ }^{38}$ Following on the redistribution / recognition model, Fraser's criterion for achieving social justice is "parity of participation" or "participatory parity." 39 
Fraser develops parity of participation as a standard for inclusion, in that a socially just society will eliminate barriers that prevent participation of all in social institutions. This means the elimination of socially constructed barriers in both the material and symbolic spheres so that all can participate as peers in social relationships and social institutions; in the economic and cultural spheres, respectively. By applying this norm, there is a possibility for some form of equality of opportunity and for all members of a society to have "the status of full partners in interaction." 40 As such, parity of participation rests on two conditions: The objective condition, that of greater equality of distribution of resources, is necessary "to ensure participants' independence and "voice" and provide "the means and opportunities to interact with others as peers." 41 The intersubjective condition means eliminating misrecognition and "requires that institutionalized patterns of cultural value express equal respect for all participants and ensure equal opportunity for achieving social esteem." ${ }^{2}$ Fraser argues that there are two distinct processes, which she terms "affirmation" and "transformation," that can help achieve participatory parity, with comprehensive social justice emerging only from the later, transformative processes. However, these processes are interlinked, so that achievement of social justice requires attention to both affirmation and transformation.

One means of reducing cultural or symbolic injustice is accordance of recognition to individuals and groups whose culture has been devalued, ignored, or considered inferior by those who have been able to exercise subordination over individuals and groups who practice that culture. Fraser terms this an affirmative approach, one of recognizing and respecting the individuals, groups, and cultures that had been misrecognized and not respected. A more radical, or what Fraser terms a transformative, approach is to deconstruct group identities and differences. This means changes that "redress disrespect by transforming the underlying cultural-valuational structure." 43

Deconstruction could transform social relationships and social institutions, leading to new and restructured identities and institutions. In her analyses, Fraser points to the need for deconstruction of difference and reconstruction of the relations of recognition. Since she considers transformative approaches to be necessary in order to achieve social justice, she cannot provide a roadmap-the form such a solution takes depends on how members of society transform social institutions. Fraser does, however, provide a guideline for reconstruction when she argues that the norm of parity of participation is the standard for overcoming misrecognition. ${ }^{44}$ Subordination "denies some individuals and groups the possibility of participating on a par with others in social interaction." ${ }^{45}$ As a corrective, she argues that "justice requires social arrangements that permit all (adult) members to interact with one another as peers." 46

Fraser does not consider multiculturalism to be sufficient to achieve participatory parity or transformation in the cultural and symbolic spheres. Rather, she argues that mainstream multiculturalism requires ongoing reallocations of respect to existing identities. This parallels a reformist approach in the economic sphere, where continual redistribution of material resources may be necessary to counter new forms of inequality. Some aspects of multiculturalism can be considered to be primarily affirmative and other aspects transformative, with the latter having the possibility of deconstructing differences, creating new social relationships and institutions, and leading to greater participatory parity. Fraser argues that mainstream multiculturalism is primarily concerned with surface reallocations of respect to identities that currently exist, without challenging or changing these identities. For Fraser, political and social solutions to injustice must move beyond affirming or recognizing difference and involve transforming society by deconstructing the meaning of difference and reconstructing the social relationships of distribution and recognition. The framework developed by Fraser provides a powerful vision of how societies can be transformed in a way that promotes social justice. Her analyses provide a way of analyzing and conceptualizing how Canadian multicultural policy is constitutive of particular social relations.

\section{Methodology \\ Data and Sampling}

The data for this article come from interviews with fiftyfive newcomers to Canada who participated in the Regina Refugee Research Project. ${ }^{47}$ Most of the newcomers arrived in Regina as government-sponsored refugees between 1985 and 1994. They were welcomed to the city by the Regina Open Door Society (RODS), a community settlement agency. To improve sample representativeness, some individuals who arrived prior to 1985 also became project participants. While the aim was to interview equal numbers of males and females, only sixteen of the fifty-five participants were female.

Table 1 compares the number of sample participants by region of origin with the number of government-sponsored refugees who arrived in Regina between 1985 and 1994. While not a random sample, the project participants constitute a cross-section of adult Regina residents who arrived as refugees between 1985 and 1994. The sample is reasonably representative of these newcomers from Southeast Asia and Africa, while it under-represents Europe and West Asia and over-represents Central and South America. 
Table 1. Number and percentage of individuals in sample and in population of arriving Regina government-sponsored refugees (1985-1994), by region of origin

\begin{tabular}{|l|r|r|r|r||}
\hline \multirow{2}{*}{$\begin{array}{c}\text { Region of } \\
\text { origin of } \\
\text { individuals }\end{array}$} & \multicolumn{2}{|c|}{ Number of individuals } & \multicolumn{2}{c|}{ Per cent of individuals } \\
\cline { 2 - 5 } & \multicolumn{1}{|c|}{ Sample } & Population. & Sample & Population. \\
\hline Southeast Asia & 17 & 572 & 31 & 31 \\
\hline $\begin{array}{l}\text { Central/South } \\
\text { America }\end{array}$ & 24 & 360 & 44 & 19 \\
\hline Europe & 4 & 365 & 7 & 20 \\
\hline Africa & 6 & 270 & 11 & 15 \\
\hline West Asia & 4 & 281 & 7 & 15 \\
\hline Total & 55 & 1,848 & 100 & 100 \\
\hline
\end{tabular}

Source: Regina Open Door Society Inc., Annual Report, 19891990 through 1993-1994. Note: Regions of origin are as follows. Southeast Asia: Cambodia, Laos, Vietnam; Central/South America: Chile, El Salvador, Guatemala, Honduras, Nicaragua; Europe: Albania, Bosnia, Bulgaria, Czechoslovakia, Hungary, Poland, Romania; Africa: Eritrea, Ethiopia, Rwanda, Somalia, Sudan, Uganda; West Asia: Afghanistan, Iran, Iraq.

\section{The Interview}

Researchers contacted newcomers and conducted semistructured interviews with newcomers in English exploring a wide range of topics such as English language acquisition, employment experiences, health and health care, and family, friends, and community. During the interview, newcomers were provided prompts meant to elicit discussions of their awareness and experiences of Canada's policy of multiculturalism. These interviews contribute to a discussion of multiculturalism in two ways. First, by providing newcomers' views, we address the concern of Bloemraad, Korteweg, and Yurdakul, who note, "Future research also needs to break down the meaning and practice of multiculturalism in different times and places." ${ }^{48}$ Second, by giving "voice" to participants and listening carefully to their narrative histories, it is possible to learn about the lived experience of the individual and the social context within which multicultural discourses are given meaning and enacted.

Newcomers' accounts of multiculturalism were coded according to five themes identified via textual analysis within the Canadian Multiculturalism Act (see Table 3). While other researchers might identify themes differently, we consider the five themes of diversity, equality, overcoming barriers, harmony, and resource to summarize the major statements of the Act. Further, the themes identified via textual analysis of the Act are similar to those identified in other discussions of multiculturalism. ${ }^{49}$ The themes refer only to statements in the Act, and not other government documents or policies. Three researchers independently read the responses and identified themes newcomers recognized. Where ratings were inconsistent, we discussed them and arrived at a mutually agreed-upon coding.

\section{Regina and Immigration}

Regina has a population of approximately two hundred thousand people, making it a medium-sized Canadian city. ${ }^{50}$ While Regina receives relatively few of immigrants to Canada, over the last thirty years there has been a small but steady flow of immigrants and refugees to Regina, with immigration to the city tripling in the last five years. ${ }^{51}$ Examining the views and experiences of newcomers to Regina is important for at least three reasons.

First, Regina is a city with a strong European multicultural heritage. In the early part of the twentieth century the population was primarily British in origin, but by the second half of the century, through migration and immigration to the city, the population became what can be termed multi-European..$^{52}$ On the ethnicity question of the 2006 Census of Canada, close to one-half of the population of the city gave single or multiple European origin responses. And the population of Aboriginal and visible minority origins reached 8.9 and 6.6 per cent, respectively, in 2006. This represents a population mix differing from that of Canada's largest metropolises..$^{53}$

Related to this is that in medium-sized cities "the process of immigrant settlement and integration may be decidedly different from and perhaps more successful than that in the largest metropolitan areas of Canada." ${ }^{4}$ One difference is that Regina has no immigrant or ethnic enclaves ${ }^{55}$ although there are areas of the city that can be considered Aboriginal neighbourhoods. ${ }^{56}$ Newcomers to Canada who reside in Regina cannot settle into a neighbourhood composed of others of their background. ${ }^{57}$

A third reason is that immigration to Regina and several other medium-sized cities is growing. From 2000 to 2010, immigration to Toronto, Montreal, or Vancouver declined from 76 per cent to 63 per cent of all Canadian immigrants while immigration to the largest Prairie cities rose from 8 per cent to 17 per cent. ${ }^{58}$ Immigration to Regina accounts for only 1 per cent of Canada's immigration but the situation in other Prairie cities may have parallels to that of Regina.

The Regina Refugee Research Project did not explore the background of participants in great detail. But all participants had been accepted by Canada as refugees, meaning that they had been displaced from their country of origin and feared persecution if they were to return. ${ }^{59}$ The two regions from which most participants came were Southeast Asia, as part of the aftermath of the war in Vietnam, and El Salvador, as a result of the civil war. ${ }^{60}$ 


\section{Findings}

\section{Awareness of Multiculturalism}

Approximately one-half (twenty-five of forty-nine) of the newcomers who responded to the prompt regarding multicultural policy were either unaware of the policy (fifteen) or demonstrated little awareness (ten). Of the latter, while some may have had a fuller understanding than evidenced in their responses, they said little more than that the policy means "a lot," is "essential," or "freedom." In contrast, many of the twenty-four newcomers who demonstrated an awareness of multiculturalism provided detailed accounts concerning its meaning. A few examples are the recognition of diversity and harmony ("lots of cultures living together in harmony"), learning from each other ("learning about other countries [and] their cultures"), and government policy ("government receives different people, different cultures and they promote it"). Some accounts indicate ambivalence, outright opposition, or a misunderstanding of the policy: "A smoke screen for Canadians [which does] nothing for me." In terms of awareness of multiculturalism, Table 2 shows that responses of Regina newcomers are almost identical to those reported for all Canadian adults and for respondents born outside Canada in Multiculturalism and Canadians: Attitude Study $1991 .^{61}$

Table 2. Level of awareness of multiculturalism, Regina participants and Multiculturalism and Canadians 1991 Survey. Percentage with each response

\begin{tabular}{|c|c|c|c|}
\hline \multirow[b]{2}{*}{$\begin{array}{c}\text { Level of } \\
\text { awareness of } \\
\text { multiculturalism }\end{array}$} & \multirow{2}{*}{$\begin{array}{c}\text { Regina } \\
\text { Refugee } \\
\text { Project } \\
\text { participants } \\
\quad(n=55)\end{array}$} & \multicolumn{2}{|c|}{1991 Survey $(n=3,325)$} \\
\hline & & $\begin{array}{c}\text { All } \\
\text { respondents }\end{array}$ & $\begin{array}{c}\text { Born } \\
\text { outside } \\
\text { Canada }\end{array}$ \\
\hline Unaware & $27 \%$ & $25 \%$ & $28 \%$ \\
\hline Little awareness & $18 \%$ & \multirow[t]{2}{*}{$63 \%$} & \multirow[t]{2}{*}{$62 \%$} \\
\hline Aware & $44 \%$ & & \\
\hline No response & $11 \%$ & $12 \%$ & $10 \%$ \\
\hline Total & $100 \%$ & $100 \%$ & $100 \%$ \\
\hline
\end{tabular}

Note: The question asked in the Multiculturalism and Canadians Survey was, "To the best of your knowledge, does the federal government have a policy of multiculturalism?" with the response being a "yes" or "no."

Several factors appear to be implicated in awareness of multicultural policy. Newcomers who indicated awareness reported their mean years of schooling was 15.0 years as compared with a mean of 11.0 years for the less aware and unaware group. ${ }^{62}$ Sixteen of the twenty-eight (57 per cent) who attended at least two English language classes reported awareness, while only five of sixteen ( 31 per cent) with less than two classes were aware of the policy. While there appeared to be no relationship between awareness of multiculturalism and the number of Canadian friends, those newcomers who reported having friends from an Aboriginal background were more likely to be aware of multiculturalism. Eleven of the sixteen newcomers who reported having an Aboriginal friend said they were aware of multicultural policy (69 per cent), as opposed to awareness by only eight of nineteen newcomers who reported no Aboriginal friend (42 per cent). This finding is interesting given that no relation was found between awareness and having friends in other ethnic groups.

Year of arrival in Regina appears strongly related to awareness of multiculturalism. Over 60 per cent of the thirty newcomers who arrived between 1988 and 1993 indicated awareness of multicultural policy; only one-quarter of the nineteen arriving earlier reported awareness. This difference may be related to the improved and more systematic settlement services that became available in the city. Several of those who arrived in the 1970s received little initial assistance. In contrast, newcomers arriving as government-sponsored refugees after the mid-1980s obtained basic settlement services from RODS, including classes in the English language and an introduction to Canadian society. Newcomers initially assisted by RODS reported greater awareness of multicultural policy than those not met or assisted by RODS. Newcomers appear to perceive RODS settlement services as indicative of state-sponsored support of multiculturalism. In addition, in the programmatic delivery of settlement services, RODS operates within an ethos of multiculturalism that can be seen as promoting the goals of the policy. Newcomers from Central America and Eastern Europe were most likely to report an awareness of Canada's policy of multiculturalism, and it was these who arrived more recently, were more likely to have been met by RODS, and had higher education levels - the latter being factors generally associated with greater awareness.

An indication that the policy of multiculturalism has met with some affirmative success in promoting recognition of the cultural and ethnic diversity of Canada and the equality of Canadians of all origins comes from the finding that newcomers identifying with both Canada and their country of origin reported a high level of awareness (fourteen of twenty-three or 61 per cent). In contrast, those identifying primarily with either Canada or their home country were less likely to report awareness (eight of twenty-two or 36 per cent). Yet, those who are aware of the policy were least likely to identify themselves as primarily Canadian. Only three of twenty-three newcomers who were aware of the policy identified themselves primarily as Canadian, compared to four of fourteen who were unaware of the policy. Awareness 
of the policy then, seems to encourage dual identification as "Canadian-plus," in which newcomers view themselves both as Canadian and as members of their country of origin. When asked "Would you encourage friends from your native land to come to Canada?" just under 60 per cent of newcomers who responded "yes" were aware of multiculturalism (twenty-two of thirty-nine). In contrast, the seven newcomers who said that they would not encourage friends to come to Canada were less aware. If encouraging newcomers to feel more Canadian by affirming recognition of their background is an objective of multicultural policy, then the policy appears to assist in this. Next, we consider the extent to which the affirmative and transformative dimensions of Fraser's analysis of multiculturalism find expression in newcomer accounts of the policy.

\section{Understandings of Multiculturalism-Affirmative or Transformative?}

In order to study newcomers' understandings of multiculturalism, we compared the accounts they offered to the themes identified via textual analysis of the Canadian Multiculturalism Act. We considered five themes to be central in the Act-these are summarized in Table 3, with references to the relevant sections of the Act. Most references are to section 3 (1) of the Act, the part that states the meaning of federal multicultural policy. In this section of the paper, we present a critical textual analysis of the CMA in the light of the analyses of Fraser, commenting on the degree to which four central issues emerging from her theoretical framework-affirmation; participation; deconstruction; and transformation-are evidenced in the narratives offered by newcomers.

Much of the discussion of multiculturalism revolves around preservation of cultures and languages, recognizing and respecting differences among groups, and solidifying group identities. In such discussions, there may be little reference to how cultures continually change, especially as people of different cultures interact with each other. The CMA contains many examples of this when it refers to respect or tolerance for cultures other than one's own, and in phrases such as "preserve, enhance and share culture" and "recognize and enhance development of communities of common origin." 63 Fraser identifies such approaches as "mainstream multiculturalism" with "surface reallocations of respect to existing identities of existing groups" that "support group identification." 64 While she does not minimize the importance of these struggles, Fraser argues that such approaches can "drastically simplify and reify group identities." 65 She refers to such approaches as affirmative, in the sense that they aim to correct injustices by providing affirmation for devalued group identities. The reallocations of respect that emerge from such initiatives do not deconstruct the manner in which the identities are formed and maintained, leaving "intact both the contents of those identities and the group differentiations that underlie them."66 In Fraser's view, such an approach often emerges from struggles for recognition and group identity.

Thematically, the CMA contains little reference to deconstructive aspects associated with difference and categorization into ethnicity, culture, and race. In fact, concepts such as "preserve" and "enhance" of the CMA may lead to emphasis on affirmation of such difference. In Fraser's approach, more attention would need to be paid to redistributive issues in the economic and material sphere in order to achieve this aspect of social justice. The statement that comes closest to matching the concept of participatory parity is from the CMA, section 3(1) (c), where multiculturalism policy is to "promote the full and equitable participation of individuals and communities of all origins in the continuing evolution and shaping of all aspects of Canadian society and assist them in the elimination of any barriers to that participation." However, the CMA does not develop this idea more fully. In light of the framework developed by Fraser, the CMA represents an ideological frame for affirmative approaches to multiculturalism and contains some statements about transformation, but is deficient in dealing with issues such as overcoming barriers, participation, and dealing with racism and discrimination.

Diversity. Affirmation of diversity is central to multicultural policy-without the fact of diversity in culture, cultural heritage, race, and language in Canadian society, there would be little need for the Act. Sub-themes are respect for diversity (also in the harmony theme), and protection and promotion of diversity (also in the resource theme). Most newcomers associated multicultural policy with diversityexamples are "a mix of cultures," "different cultures, different people," and "different heritage, different culture, different language."

Equality. Diversity alone could be associated with inequality, antagonism, or conflict among individuals and groups. Regardless of the reality, the Act states that equality is a policy aim, through "equal treatment and equal protection," "equitable participation," and "equal opportunity." None of these implies that individuals will be equal in terms of income, wealth, or condition, but one goal of the Act is to set out several aspects of equality among individuals and groups. Seven of the accounts reflected the goal of equality as embodied in the Act. Newcomers noted, "we are all equal, all Canadians were immigrants at one time," "equality, friendship, and respect between each other," and "society which is just, where equal participation can take place." One newcomer provided a very concrete account of equality 
Table 3. Textual analysis: Themes in the Canadian Multiculturalism Act

\begin{tabular}{|c|c|c|}
\hline Theme & Affirmative & Transformative \\
\hline Diversity & $\begin{array}{l}\text { - cultural and racial diversity of Canadian } \\
\text { society 3:1(a) } \\
\text { - } \text { preservation, enhancement and sharing of } \\
\text { cultural heritage } 3: 1(\mathrm{a}) \\
\text { - recognize the existence of diverse commun- } \\
\text { ities } 3: 1(\mathrm{~d}) \\
\text { - } \text { respecting and valuing diversity } 3: 1(\mathrm{e})\end{array}$ & $\begin{array}{l}\text { - promote reflection and evolving expression } \\
\text { of cultures } 3: 1(\mathrm{~h})\end{array}$ \\
\hline Equality & $\begin{array}{l}\text { - equal treatment and protection under law } \\
3: 1(\mathrm{e}) \\
\text { - equal opportunity in federal institutions 3:2(a) }\end{array}$ & $\begin{array}{l}\text { - full and equitable participation of individuals } \\
\text { and communities in the continuing evolution } \\
\text { and shaping of Canadian society } 3: 1(\mathrm{c})\end{array}$ \\
\hline Harmony & $\begin{array}{l}\text { - harmony, respect, appreciation, and under- } \\
\text { standing 3:1(f) and (j) }\end{array}$ & $\begin{array}{l}\text { - exchanges and cooperation among the } \\
\text { diverse communities } 5: 1 \text { (c) }\end{array}$ \\
\hline Overcoming barriers & - eliminate barriers to participation 3:1(c) & - encourage institutions to be inclusive $3: 1(f)$ \\
\hline Resource & $\begin{array}{l}\text { - fundamental to Canadian heritage and iden- } \\
\text { tity } 3: 1(b) \\
\text { - historic contribution to Canadian society } \\
3: 1(\mathrm{~d}) \\
\text { - make use of language skill and cultural } \\
\text { understanding 3:2(e) } \\
\text { - value diversity } 3: 1(\mathrm{e})\end{array}$ & $\begin{array}{l}\text { - creativity } 3: 1(\mathrm{~g}) \\
\text { - invaluable resource in shaping Canada's } \\
\text { future 3:1(b) }\end{array}$ \\
\hline
\end{tabular}

Note: The numbers and letters in the box refer to the sections or subsections of the Canadian Multiculturalism Act.

rights by stating: "Being able to participate in Canadian society. For example, having the right to vote."

Harmony. We attached this label to concepts such as respect, recognition, appreciation, and understanding. While, in practice, relationships among diverse groups and efforts to reduce barriers to full and equal participation may not be carried out harmoniously, the Act mandates this direction. By indicating that Canadians should respect and appreciate various diverse cultures and traditions, a certain harmony is implied by the Act. Newcomer accounts that drew upon rhetorical framing of Canadian multicultural policy such as "many people work together looking for better life" and "one culture and another come together, bring cultures together" express this theme most clearly. Many accounts employ similar rhetorical devices and this was the second most widely expressed theme by the newcomers.

Overcoming Barriers. Given the many forms of inequality in Canadian society, it is interesting that the framers of the Act noted a need to eliminate barriers. The specific types of barriers and how these might be overcome are not discussed in the Act, but there is some recognition of maldistribution. Section 3:1 (f) refers to assisting a variety of institutions to be inclusive, the implication being that some institutions are not inclusive in their practices. While three newcomers appeared to express this theme, their accounts concerning barriers to jobs and education and "opportunities ... to develop or act" do so only implicitly. Given the limited and peripheral reference to overcoming barriers in the Act, it is perhaps not surprising that none of the newcomers' accounts included explicit recognition of this theme. In fact, some of those who reacted negatively or with ambivalence to the policy noted that a missing element of multiculturalism was its inability to assist in overcoming barriers to fuller social participation.

Resource. Statements in the Act express the idea that multiculturalism and diversity are or can be resources integral to Canadian heritage and identity and are important for shaping and building Canada. In this theme, diversity is considered creative, skills are provided, understanding is increased, and Canadian society is transformed. This was the second least expressed theme in the newcomers' accounts and again, most statements were no more than implicit. Perhaps the clearest narratives were those of the newcomers who noted that "cultures contribute to [the] culture of Canada" and "means we are people from different countries, but have the same responsibilities for our society."

Most newcomers identified the diversity theme, with just over 40 per cent also making some reference to harmonious 
relationships. Approximately one-quarter of the aware newcomers expressed some notion of multiculturalism as equality or resource. The bulk of statements about the meaning of multiculturalism made reference to what Fraser terms the affirmative aspects of multiculturalism. Words used in connection with diversity that the researchers considered to express this approach include "equality," "respect," "friendship," "family," "harmony" "share," "preserve," and "appreciate." We also considered responses such as "different heritage, different culture, and different language are considered a good thing" and "government receives different people, different cultures and they promote it. There is not laws against it like in some countries. There is freedom of religion and culture" as expressing affirmation. For the most part, the latter accounts are associated with a vision of multiculturalism as one of different cultures and peoples who coexist or get along with each other. But these phrases do not present a view of cultures as changing or society as being transformed. Each of the above accounts represents a view of multiculturalism that is consistent with much of the official discourse of Canadian multiculturalism. Such statements are examples of an affirmative view that accords respect to cultures other than one's own, without envisioning possibilities for multiculturalism as being transformative. In addition, newcomers identified other factors they felt were associated with multiculturalism-we now turn to these.

Freedom. Four newcomers mentioned freedom with the clearest expressions being "There is freedom of religion and culture," "free for everyone," and "freedom." While section 3:1 (a) states "freedom of all members of Canadian society to preserve, enhance and share their cultural heritage," the Act emphasizes affirmative approaches to cultural diversity and maintenance of culture, rather than promoting the transformative potential of freedom. In this respect, the account "That people have freedom to speech, religion, culture, jobs, and education" is interesting. While the first three mentioned freedoms clearly fit into the policy, the latter two do not appear in the Act. Newcomers' accounts articulated serious concerns about maldistribution of employment and educational opportunities that were not addressed by multicultural policy. When asked what aspects of their new lives present the greatest problem and what changes would make life a lot better, fourteen newcomers specifically directed their narratives to employment difficulties.

Participation. Following Fraser's criticisms of multiculturalism, we did not identify participation as a major theme in the Act although section 3:1 (c) states that the policy is to "promote the full and equal participation of individuals and communities of all origin ..." Several newcomers identified participation as key, for example, "participate in Canadian society," "where equal participation can take place," and "opportunities for all groups, cultures, or persons to develop or act within their community." Others noted that it is possible to "sample of [the] best elements in every culture" or expressed the idea of peaceful coexistence: "lots of cultures living together in harmony." One newcomer said multiculturalism "means we are people from different countries, but have the same responsibilities for our society." What is interesting about the latter account is that it extends individual or group action beyond participation, to responsibility. As the next section will discuss, this is reminiscent of some contemporary discussions on citizenship, ${ }^{67}$ but appears to be beyond multicultural policy, at least as expressed in the Act.

Rights and Privileges. Six newcomer accounts identified rights or privileges they felt were guaranteed by the policy. One explained, "There is freedom of religion and culture" and another indicated the right to "exercise language and customs so long as it doesn't affect someone else." The latter is an example of a commonly expressed theme-affirmative aspects of multicultural policy are moderated to allow development of a greater sense of Canadian cultural unity.

Critical View. While most newcomers who provided accounts of multicultural policy evaluated it positively, three newcomers expressed serious reservations toward the policy, providing their own variant of Fraser's criticism that multiculturalism is merely affirmative. One newcomer, apparently frustrated by the policy, referred to it as "A smoke screen for Canadians which does nothing for me." Two accounts provide illustrations of the failure of multicultural policy to fulfill transformative purposes as articulated by newcomers: "Activities may help but doesn't help integration, but can help preserve culture" and "[I] like it and hate it at the same time. We can live in our culture but we are called minority groups. Appears on job applications. You are different. Never part of the total." As used by Fraser, "deconstruction" involves eliminating such socially constructed differences that impede parity of participation. In connection with multiculturalism, this involves deconstructing race, ethnicity, national origin, and religion in a way such that differences associated with these categories no longer impede the ability of anyone to participate as a peer in social institutions and relationships. There were few accounts that mentioned culture and social life in a way that implies change that could produce a new culture and way of life. As compared with Canadian multicultural policy, a few of the accounts appear to place an even greater emphasis on the transformative potential of promoting Canadian cultural unity through mutual respect for diversity. Consider the following account: "Putting together people from different cultures to be unified in one idea and to learn each from the other and to live together." This account pulls 
together themes of diversity, harmony, and resource. The view expressed is one of creating a new culture. This implies some deconstruction of differences created by earlier cultures, so that new social relationships and culture emerge. The above statements certainly contrast with affirmative accounts such as "practice your own culture," where no change in culture is suggested.

\section{Discussion}

\section{Multicultural Relations of Ruling}

Analysis of newcomers' accounts in this article this has been an exercise in research concerning understandings of the public policy of multiculturalism. Issues of social justice are central to a critical understanding of multiculturalism and several interrelated conclusions emerge from this study, which demonstrates how Canadian multicultural policy is constituent of ruling relations. Newcomer accounts do not always match the concepts and approaches of Fraser, although some participants made statements that point toward multiculturalism as a transformative social process that can lead to social change. While many of the accounts presented no more than an affirmative approach to multiculturalism, few stated that multiculturalism was a way of transforming social relationships. Many of the statements implied little more than an affirmative form of relationship - that of respect, harmony, and understanding-and few had more dynamic implications. The latter tended to consider individuals and groups of different cultural backgrounds to be actively involved in interaction, sharing, working together, and creating a new or different culture and set of social relationships.

Of the five themes embedded in the Canadian Multiculturalism Act, overcoming barriers was the theme newcomers' accounts were least likely to employ as interpretive resources. "Overcoming barriers" refers to ways of creating equal participation and life chances for all Canadians, regardless of their cultural heritage. Given that employment and educational opportunities are central issues for newcomers, multicultural policy could have great relevance by promoting these. If newcomers to Canada are unaware of guarantees to full and equal participation, they are unlikely to seek redress when they encounter such barriers. Newcomers may suffer in silence, unaware of the legislative commitment to removing such barriers. This is a key area, one that educational programs could beneficially address.

Many critics have considered the promise entailed in multicultural policy and the Act as unfulfilled. A key element of a sociological understanding of multiculturalism relates to the power relationships between cultural minorities and the majority. To the extent that maldistribution is not addressed and economic and social inequalities among ethnic groups persist, multicultural policy can be viewed as having failed to achieve its transformative potential. This failure has direct and concrete effects on the lives and social realities of newcomers. One concrete manifestation of this is the inability of some members of such groups to gain educational and employment opportunities equal to those of other Canadians or exercise rights that other groups take for granted.

Related to this is multiculturalism as a resource for developing and shaping Canada's future. Only one-quarter of aware newcomers identified this theme, yet unique cultural characteristics can provide valuable resources, relevant for the life chances of all Canadians. From a social policy standpoint, Canadians could be encouraged to view the wide variety of cultural attributes and skills of newcomers as a valuable resource to transform Canadian society, where the potential benefits of the attributes and skills of both newcomers and all Canadians are realized.

An understanding of multiculturalism that is limited to affirming diversity is limited. The theme of affirming diversity found expression in nearly three-quarters of the accounts offered by newcomers, yet only about one-half of these accompanied this with an understanding equality and harmony as part of multiculturalism. History provides many examples of the danger associated with a narrow conception of diversity, one that is not tempered with mutual understanding, respect, tolerance, equality, and harmony.

Each of the five major themes from the Canadian Multiculturalism Act found at least some level of expression in newcomer accounts. The public framing of Canadian multicultural policy appears to act as an interpretive resource upon which newcomers draw in their own accounting of their experiences of multiculturalism. At the same time, in no case did any single newcomer identify all five themes, and most identified only one or two themes. Most accounts articulated the affirmative emphasis of the policy rather than more transformative aspects. Since multicultural policy is so potentially relevant to the lives of newcomers, policy makers could undertake greater efforts to develop clearer understandings of multicultural policy. For example, language programs and settlement agencies both help promote Canada's multicultural policy and assist newcomers in participating in Canadian society and improving their life chances. Such programs and agencies could be strengthened as resources to help achieve these dual goals.

For Fraser, the criterion for a socially just transformation is parity of participation. Such participatory parity must be rooted in social institutions and not merely in interpersonal psychology 68 meaning "participatory parity as a normative standard." 69 One example of reconstruction that Fraser 
provides is that of practices that marginalize or exclude ethnic and religious minorities in France. Fraser argues that affirmative steps to include minorities could have transformative consequences such as "reconstructing French national identity to suit a multicultural society" and "refashioning Islam for a liberal-pluralist and gender-egalitarian regime."70 This example illustrates a transformative solution that focuses primarily on eliminating institutionalized disparities in participation. In other cases, transformation may require more attention to deconstructing differences that impair such participation.

Fraser considers deconstruction of socially constructed identities and differences to be central to achieving a transformation in a socially just direction. For her, this involves deconstructing identities associated with race, ethnicity, sexuality, and gender. By changing the structure and operation of its institutions and social relationships, the practice of multiculturalism can be a way for a diverse society to transform itself. A society where principles of multiculturalism-equality, respect, harmony, recognition, participation-are practiced will attempt to find ways of integrating members from all backgrounds and cultures, allowing all to participate in social life. While it is difficult to predict the direction this may lead, it is unlikely to leave social relationships and social institutions unchanged. Social interaction on the basis of the principles and practices of multiculturalism can help produce a more socially just outcome, with improved opportunities for all to participate in the life of society. The majority of newcomers expressed a desire that both they and their family maintain aspects of their cultural heritage, and it is this affirmation that multicultural policies have been most successful at supporting. In addition, newcomers' accounts articulated a desire to establish the types of services for their ethnic communities that multicultural policies can in some cases help facilitate greater participation-services such as meeting places, place of worship, and language schools.

\section{Conclusion}

\section{Recognition of a "Great" Large Family}

In terms of future research, we encourage other researchers to further investigate what Canadians understand by multiculturalism. This project has found that several factors associated with the social lives and life chances of newcomers are positively related to the potentialities of multicultural policy for the affirmation of cultural difference. While some of these findings should encourage multicultural policy makers, these results must be regarded as tentative because of the small sample size and the exploratory nature of this analysis. For example, it would be useful to compare the accounts given by this study's newcomers with other groups of immigrants and Canadian-born. Surveys related to multiculturalism often ask people to evaluate the policy and concept, but there appears to be less investigation of the different perceptions of and experiences with multiculturalism. Further research is needed to investigate the relational processes in which differing perceptions of and experiences with multiculturalism are embedded and to compare the present accounts with those of other groups of immigrants and Canadian-born.

In the future, Canadians will continue to welcome individuals and groups from different geographic regions with a variety of cultural histories and experiences. Will the social intolerance and injustice that often characterized the past be repeated, or will Canadian society find new ways of recognizing a "great" large family? One way that societies can transform themselves is by learning from other societies, cultures, and peoples and by incorporating this learning into societal practices. Integration can be considered a two-directional process. One part of the process is that newcomers to a society change their practices and views as they incorporate themselves in the society. At the same time, a truly transformative process will change the society into which newcomers enter, and the social relations and institutions will change in the society.

Following Fraser, socially just multicultural policies require those who were members of the society prior to newcomers arriving to also change their social practices so that all members of the society can participate in social life as peers. The accounts studied here demonstrate an appreciation of diversity and a view that diversity provides a way of learning and tackling problems. New cultural traditions and experiences will be created within Canada, leading to new groups and identities. Based on the accounts articulated by the newcomers studied here, the authors agree that newcomers "typically wish to integrate into the larger society, and to be accepted as full members of it"71 and that many of the rights such newcomers expect "promote integration into the larger society." 72 The newcomers in this project appear to have generally accepted and adopted this affirmative approach-and as they were refugees originally, Canada may not have been their first choice of new home. Given this evidence, we are optimistic about the future. Multicultural principles have already become part of the Canadian identity and may assist in the future transformation of Canadian culture and identity.

\section{Notes}

1. Department of the Secretary of State of Canada, Multiculturalism ... Being Canadian, (Ottawa: Ministry of Supply and Services, 1987), 9. 
2. Peter S. Li, "The Multiculturalism Debate," in Race and Ethnic Relations in Canada, 2nd ed. (Don Mills: Oxford University Press, 1999).

3. For a recent review of these debates, see Keith Banting and Will Kymlicka, "Canadian Multiculturalism: Global Anxieties and Local Debates," British Journal of Canadian Studies 23, no. 1 (2010): 43-72.

4. Several writers have urged researchers to develop and analyze empirical evidence as a means of contributing to the debates. Joseph Garcea, "Postulations on the Fragmentary Effects of Multiculturalism in Canada," Canadian Ethnic Studies, 40, no. 1(2008): 141-60, argues for investigating "real and perceived problems at the substantive and symbolic levels," 156. Irene Bloemraad, Anna Korteweg, and Gökçe Yurdakul note, "The explosion of scholarly interest in multiculturalism during the 1990s largely revolved around normative theory, with few empirical studies analyzing specific policies and their consequences," page 160 in "Citizenship and Immigration: Multiculturalism, Assimilation, and Challenges to the Nation-State," Annual Review of Sociology 34, (2008): 153-79. Kymlicka argues that research findings have been ignored in public commentary on multiculturalism. See Will Kymlicka, The Current State of Multiculturalism in Canada and Research Themes on Canadian Multiculturalism 2008-2010, Citizenship and Immigration Canada, Catalogue No. Ci96-112/2010E-PDF, Ottawa, 2010, 11.

5. A notable exception is Labelle and Salee's study of the perceptions of immigrants to Quebec; see Micheline Labelle and Daniel Salée, "Immigrant and Minority Representations of Citizenship in Quebec," in Citizens Today: Global Perspectives and Practices, ed. T. Alexander Aleinikoff and Douglas Klusmeyer (Washington: Carnegie Endowment for International Peace, 2001).

6. Roxana Ng, "Multiculturalism as Ideology: A Textual Analysis," in Knowledge, Experience, and Ruling Relations, ed. Marie Campbell and Ann Manicom (Toronto: University of Toronto Press, 1995), 36.

7. Dorothy Smith, Texts, Facts, and Femininity: Exploring Relations of Ruling (New York: Routledge, 1990), 125.

8. While multiculturalism addresses social relationships among all individuals and groups, the focus for this article is on immigration and multiculturalism.

9. Banting and Kymlicka, "Canadian Multiculturalism," 57-62, review Canadian responses to immigration and multiculturalism.

10. Recent and earlier estimates of inequalities for minorities are examined and reviewed in Krishna Pendakur and Ravi Pendakur, "Colour by Numbers: Minority Earnings in Canada 1996-2006," accessed April 5, 2011, http://www .sfu.ca/ pendakur/Colour\%20By\%20Numbers.pdf.

11. John W. Berry, Rudolf Kain, and Donald M. Taylor, Multiculturalism and Ethnic Attitudes in Canada (Ottawa: Ministry of Supply, 1977), 11; Canada, Department of Canadian Heritage, Strategic Evaluation of Multiculturalism
Programs: Final Report, study conducted by Brighton Research (Ottawa: Corporate Review Branch, 1996), 12; Richard J. F. Day, Multiculturalism and the History of Canadian Diversity (Toronto: University of Toronto Press, 2000).

12. Garth Stevenson reviews the history of multiculturalism in Canada in "Contrasting Images: 'Multiculturalism' as conceptualized in Canada and the United States," paper prepared for presentation at the annual meeting of the Canadian Political Science Association, Montreal, June 3, 2010, accessed April 4, 2011, http://www.cpsa-acsp.ca/ papers-2010/Stevenson.pdf.

13. Jean R. Burnet and Howard Palmer, Coming Canadians: An Introduction to a History of Canada's Peoples (Toronto: McClelland and Stewart, 1988), 224; Charles S. Ungerleider, "Immigration, Multiculturalism, and Citizenship: The Development of the Canadian Social Justice Infrastructure," Canadian Ethnic Studies 24, no. 3 (1992): 14.

14. Accessed April 6, 2011, http://canadachannel.ca/HCO/ index.php/Pierre_Trudeau,_on_Multiculturalism.

15. Yasmeen Abu-Laban and Tim Nieguth, "Reconsidering the Constitution, Minorities, and Politics in Canada," Canadian Journal of Political Science 33, no. 3 (2000): 491.

16. Canada, Department of Canadian Heritage, Strategic Evaluation of Multiculturalism Programs.

17. Canada, Department of Canadian Heritage, $10^{\text {th }}$ Annual Report on the Operation of the Canadian Multiculturalism Act, p. v (Ottawa: Minister of Public Works and Government Services, 1999), accessed April 6, 2011, http://dsp-psd .pwgsc.gc.ca/Collection/Ci95-1-1998E.pdf.

18. Citizenship and Immigration Canada, Annual Report on the Operation of the Canadian Multiculturalism Act, 20072008, Catalogue Number CH31-1é2008, Ottawa, 2009.

19. Citizenship and Immigration Canada, Multiculturalism and Canadian Multiculturalism: An Inclusive Citizenship, accessed April 5, 2011, http://www.cic.gc.ca/english/multiculturalism/index.asp.

20. See the annual reports from Canadian Heritage and Citizenship and Immigration Canada, Annual Report on the Operation of the Canadian Multiculturalism Act.

21. Angus Reid Group, Inc., "Multiculturalism and Canadians: Attitude Study 1991," National Survey Report (1991); Reginald W. Bibby, The Bibby Report: Social Trends Canadian Style (Toronto: Stoddart, 1995), 38-39; Canada, Department of Canadian Heritage, Strategic Evaluation of Multiculturalism Programs, 38-42.

22. Charles Taylor, "The Politics of Recognition," in Multiculturalism and the "Politics of Recognition," ed. Amy Gutman (Princeton: Princeton University Press, 1992); Will Kymlicka, Multicultural Citizenship: A Liberal Theory of Minority Rights (Oxford: Clarendon Press, 1995); Will Kymlicka, Finding Our Way: Rethinking Ethnocultural Relations in Canada (Toronto: Oxford University Press, 1998).

23. Karl Peter, "The Myth of Multiculturalism and Other Political Fables," in Ethnicity, Power and Politics in Canada, 
ed. Jorgen Dablie and Tissa Fernando (Toronto: Methuen, 1981); Reginald W. Bibby, Mosaic Madness: Pluralism with out a Cause (Toronto: Stoddart, 1990).

24. Neil Bissoondath, Selling Illusions: The Cult of Multiculturalism in Canada (Toronto: Penguin Books, 1994).

25. See discussion in: Yasmeen Abu-Laban and Daiva Stasiulis, "Ethnic Pluralism under Siege: Popular and Partisan Opposition to Multiculturalism," in Canadian Public Policy 18, no. 4 (1992): 365-86; also Augie Fleras and Jean Leonard Elliot, Multiculturalism in Canada: The Challenge of Diversity, 2nd ed. (Scarborough: Nelson Canada, 2002); Li, "The Multiculturalism Debate."

26. Bohdan S. Kordan, "Multiculturalism, Citizenship and the Canadian Nation: A Critique of the Proposed Redesign for Program Renewal," Canadian Ethnic Studies 29, no. 2 (1997):136-43; Abu-Laban and Nieguth, "Reconsidering the Constitution."

27. Kymlicka, Multicultural Citizenship; Kymlicka, Finding Our Way.

28. Ng, "Multiculturalism as Ideology," 35.

29. Nancy Fraser, "From Redistribution to Recognition? Dilemmas of Justice in a 'Post-Socialist' Age," New Left Review, 1 / 212, (1995): 68-93; Nancy Fraser, Justice Interruptus: Critical Reflections on the "Postsocialist" Condition (New York: Routledge, 1997); Nancy Fraser, "Rethinking Recognition," New Left Review 3 (2000): 107-20; Nancy Fraser and Axel Honneth, Redistribution or Recognition? A Political-Philosophical Exchange (New York: Verso, 2003).

30. Fraser, Justice Interruptus, 152.

31. Fraser and Honneth, Redistribution or Recognition?, 49.

32. Ibid., 17.

33. Fraser, "From Redistribution to Recognition?"; Fraser, Justice Interruptus; Fraser, "Rethinking Recognition"; Fraser and Honneth, Redistribution or Recognition?.

34. In their co-authored book, Fraser debates this point with Axel Honneth, who argues that there is only one dimension of social injustice, that of recognition, with maldistribution emerging from misrecognition; see Fraser and Honneth, Redistribution or Recognition?

35. Nancy Fraser, "Reframing Justice in a Globalizing World," New Left Review, 36 (2005) 69-88; Nancy Fraser, Scales of Justice: Reimagining Political Space in a Globalizing World (New York: Columbia University Press, 2009).

36. Fraser, "From Redistribution to Recognition," 70-71.

37. Ibid., 73.

38. In her recent work, Fraser argues that the concept of citizenship or member of society is increasingly untenable (see Fraser, "Reframing Justice"; Fraser, Scales of Justice). In this paper, we do not address the issues associated with multiple and shifting citizenship.

39. Fraser and Honneth, Redistribution or Recognition?, 38.

40. Ibid., 36.

41. Ibid.

42. Ibid.

43. Fraser, "From Redistribution to Recognition," 83.
44. Fraser and Honneth, Redistribution or Recognition?, 31.

45. Ibid.

46. Ibid., 36 .

47. The project was conducted between 1993 and 1995. The goal of the project was to examine settlement programs and immigrant integration in Regina and investigate the meaning of successful settlement. The funding for the project originated from a grant by the Department of the Secretary of State of Canada to the Saskatchewan Association of Immigrant Settlement and Integration Agencies.

48. Bloemraad, Korteweg and Yurdakul, "Citizenship and Immigration," 161.

49. Ng, "Multiculturalism as Ideology," 38-45; Fleras and Elliot, Multiculturalism in Canada, 62-65.

50. Between 1991 and 2006, the population of Regina remained around 179,000. Recent expansion has increased the population and the population of the Census Metropolitan Area was estimated to be 215,000 people in 2010. See Statistics Canada, 2006 Census of Canada, "Population of Census Metropolitan Areas," accessed April 3, 2011, http://www40 .statcan.gc.ca/101/cst01/demo05a-eng.htm.

51. Citizenship and Immigration Canada, Fact and Figures 2009: Immigrant Overview-Permanent and Temporary Residents (Ottawa: Citizenship and Immigration Canada, 2010). There were 2,058 permanent resident immigrants who gave Regina as their destination in 2010.

52. In the 1931 Census of Canada, 69 per cent of the population gave British origins and 30 per cent gave other European origins. Given the mixed origins that have become common in more recent years, with single, multiple, Canadian, and North American origins that respondents provide in recent censuses, it is not possible to obtain precise summary estimates of the ethnic origin of the current population. From data in the 2006 Census of Canada we estimate the current ethnic mix of Regina to be approximately 33 per cent British, 8 per cent French, and 43 per cent other European, recognizing that these estimates are rough. From the Census, 9 per cent of Regina residents were Aboriginal and 7 per cent visible minority origin in 2006.

53. From the 2006 Census of Canada, the population of Toronto and Vancouver was over 40 per cent visible minority. And, unlike Montreal, Regina has few residents of French origin. Statistics Canada, 2006 Census of Population, "Profile of Ethnic Origin and Visible Minorities for Census Metropolitan Areas and Census Agglomerations," Statistics Canada catalogue no. 94-580-XCB2006004.

54. Baha Abu-Laban, "Application to SSHRC for the Establishment of a Centre of Excellence for Research on Immigration and Immigrant Integration" (Edmonton: University of Alberta, 1995), 1.

55. In the 2006 Census of Canada, no one ethnic group accounted for more than 7.6 per cent of any Regina census tract. And in no census tract do the number of immigrants who arrived in the city since 1980 account for 20 per 
cent of the population. Qadeer, Agrawal, and Lovell state: "Anywhere from $10 \%$ to $30 \%$ of a census tract's population being of a specific ethnic background has been used as the criteria for identifying ethnic enclaves"; see Mohammad Qadeer, Sandeep K. Agrawal, and Alexander Lovell, "Evolution of Ethnic Enclaves in the Toronto Metropolitan Area, 2001-2006," Journal of International Migration and Integration 11 (2010): 323-24.

56. Individuals of Aboriginal identity account for more than 30 per cent of the population in three (two of which are adjacent) of Regina's fifty-two census tracts.

57. See Feng Hou and Garnett Picot, "Visible Minority Neighbourhoods in Toronto, Montreal, and Vancouver," Canadian Social Trends (Spring 2004): 8-13.

58. These are the seven largest Prairie cities: Edmonton, Red Deer, Calgary, Lethbridge, Saskatoon, Regina, and Winnipeg. Calculated from Citizenship and Immigration Canada, Fact and Figures 2009: Immigrant Overview - Permanent and Temporary Residents and Preliminary Tables-Permanent and temporary residents, 2010, http://www.cic.gc.ca/ english/resources/statistics/menu-fact.asp.

59. Many were convention refugees or persons in need of protection. For current definitions, see Citizenship and Immigration Canada, Refugee claims in Canada - who can apply, accessed April 8, 2011, http://www.cic.gc.ca/english/ refugees/inside/apply-who.asp.

60. Of the 55 participants, 17 were originally from Cambodia, Laos, or Vietnam and 21 were from El Salvador. For a discussion of the background and experiences with integration in Regina of Salvadorans, see Doug Durst and Allison Lange, "Prairie Adjustments and the Social Integration of El Salvador Refugees in Regina, Saskatchewan," Prairie Forum 27, no. 1 (2002): 101-14. While we are unaware of any comparable Regina study of those from Southeast Asia, the volumes edited by Dorais, Chan, and Indra provide extensive analysis of their experiences in other parts of Canada. See Kwok B. Chan and Doreen M. Indra, eds., Uprooting, Loss and Adaptation: The Resettlement of Indochinese Refugees in Canada (Ottawa: Canadian Public Health Association, 1987); and Louis-Jacques Dorais, Kwok B. Chan, and Doreen M. Indra, eds., Ten Years Later: Indochinese Communities in Canada (Montreal: Canadian Asian Studies Association, 1988).
61. Canadian Heritage generously provided the authors with a copy of the data file from the Multiculturalism and Canadians survey conducted by the Angus Reid Group, 1991.

62. For the aware group, $n=24$, the mean years of schooling was 15.0 with a standard deviation of 4.0 , and for the less aware and unaware group, $\mathrm{n}=25$, the mean was 11.0 with a standard deviation of 4.7. This produces a t-value of 3.16. If the sample were a random sample, this would produce a one-tailed significance of less than 0.002 . We report significance levels even though the project sample was not random. As a result, reported significance levels may not be very precise or meaningful, and we leave their interpretation to the reader.

63. CMA, sections 3:1 (a) and (d), 5:1 (e) and (h).

64. Fraser, "From Redistribution to Recognition?", 87.

65. Fraser, "Rethinking Recognition," 108.

66. Fraser, "From Redistribution to Recognition?", 82.

67. Will Kymlicka and Wayne Norman, eds., Citizenship in Diverse Societies (New York: Oxford University Press, 2000), 5. Also see Kymlicka's comments on citizenization in Will Kymlicka, "The Rise and Fall of Multiculturalism? New Debates on Inclusion and Accommodation in Diverse Societies," International Social Science Journal 199 (2010): 100.

68. Fraser and Honneth, Redistribution or Recognition?, 31.

69. Fraser, "Rethinking Recognition," 119.

70. Ibid., 82.

71. Kymlicka, Multicultural Citizenship, 10-11.

72. Ibid., 31

Christopher J. Fries is a sociologist of health, medicine, and the body, in the Department of Sociology, University of Manitoba, whose primary research interests are in health lifestyles, critical public health, the social determinants of health, and medical pluralism. He is co-author of Pursuing Health and Wellness Healthy Societies, Healthy People (Oxford University Press, 2011).

Paul Gingrich is professor emeritus of sociology and social studies, University of Regina, Saskatchewan. 